\title{
Editorial Structure and Editing Task in Soleh Solihun "Mau Jadi Apa?" movies and their Implication in Introduction to Journalism course
}

\author{
Utami Dewi Pramesti, Yulianti Rasyid \\ Universitas Negeri Padang \\ dpramesti0405@gmail.com
}

\begin{abstract}
This article described the structure and tasks of editing in the campus press, exactly at Universitas Padjadjaran (UNPAD) in period 1998s named Karung Goni. This press was formed by a student group led by Soleh (as the main character) in the movie "Mau Jadi apa?" written by Soleh Solihun. The purpose of this study was to know and to understand the structure and editing tasks in the campus press which has implications for Journalistic elective course. The type of research used was qualitative-descriptive with content analysis technique. In general, the steps of the study were data reduction, data presentation, and conclusions. The findings of the analysis suggest that the organizational structure in Karung Goni is categorized as qualified as a mass media. However, there is still weakness as there are still members who play a double role.
\end{abstract}

Keywords--structure and tasks of editing, movies, Soleh Solihun, Journalistic course.

\section{INTRODUCTION}

Definition of film, -according to Constitution no. 8/year 1992 in Joseph (2011), as a work of art and culture creation and mass media of hearing-sight which are based on cinematographic principles recorded on celluloid bands, video tapes, video disks, and / or other technological inventions in all forms, types and sizes through chemical, electronic, or other processes, with or without sound, which may be demonstrated and / or represented by a mechanical, electronic, and / or other projection system. Since this media combines the role of the sense of sight and hearing, finally making a film tend to attract more public attention. Especially in this digital era, the film is one of the most popular entertainment media in the community.

According to this research data, the object of study is the movie "Mau Jadi Apa?" directed by Soleh Solihun. JawaPos newspaper (2017) stated that the comedy genre "Mau Jadi Apa?" received quite good enthusiasm from the audience in the country. Since launching on November 30, 2017, the film that tells the life of Soleh Solihun has been watched more than 80 thousand people. As reported by filmindonesia.or.id, the film has got 80,105 spectators. The number increased to 100 thousand more viewers by the end of December 2017.

The film is produced by Starvision and Millennia. The film was directed by Monty Tiwa and Soleh Solihun. Film "Mau Jadi Apa?" contains the life story of Soleh Solihun who also acts as the main character along with other actors such as Lukman played by Boris Bokir ("Rudy Habibie", "Toba Dreams"), Marsyel is performed by Adjis Doaibu ("Cek Toko Sebelah", "From London to Bali"), Awwe (Ada Cinta di Sekolah, Total Chaos) as Eko, Sharif is played by Ricky Wattimena, Anggika Bolsterli ("Koala Kumal," "Trinity”, "the Nekad Traveler") who plays Fey and the ideal girl of Soleh, Ros, played by Aurelie Moeremans (Pramudya, 2017).

In the film, Soleh was a student of the Faculty of Communication Sciences, Padjadjaran University in Bandung in the late 1990s and early 2000s. The most important thing in this film is the ins and outs of the student life majoring in Communication Studies which is closely related to journalism with its entire trivia. Due to its journalistic aspirations, this study is needed as an initial material for the selection and development of this film as an instructional media in journalistic course. Instructional media is a medium that can carry messages or information with instructional-oriented or contains learning purposes (Arsyad, 2007).

The related journalistic material in the discussion of this article is about the press, especially the campus press or the student press. Theoretically, the press system adopted in Indonesia is the Social Responsibility system where the press acts as a social control for the people (Rashid, 2011). Based on the Constitution of the Republic of Indonesia Number 40 Year 1999 regarding the press, it is said in article 1 verse 1 that "The press is a social institution and a medium of mass communication that carries out journalistic activities including seeking, obtaining, owning, storing, processing, and conveying information in the form of writing, sound, pictures, sounds and images, as well as data and graphics or in other forms using print media, electronic media, and all types of channels available." In Indonesia, the campus press is a mass media held and managed by students in a college. The products produced in the form of magazines, journals, bulletins, tabloids, or newspapers with market share among students themselves (Juniarti, 2012). The campus press discussed in this article is named Karung Goni. 
Karung Goni is a campus press or student press formed by a group of students of FISIP UNPAD class of 1998 consisting of Soleh, Lukman, Eko, Syarif, Fey, Marcel, and Rusli. Explicitly, KG is actually a tabloid formed based on the principle of friendship. This tabloid was initiated by Soleh group as an effort to present alternative reading of student press besides tabloid that already exist namely Fak-Jat (acronym from Jatinangor Facts) which tend to be serious and boring. Based on the initial goal, the presence of this tabloid tends to be more fun. This actually corresponds to its name: Kabar-Ungkapan-Gombalan/Gosip-Opini which thereby abbreviated as Karung Goni. Due to the limited nature and membership, the structure and editing task in this tabloid was made quite unique.

The editors are a group of people in a mass media institution working on a common goal. Habibi (2010) reveals that the editing aim /object is to prepare the task of mass media journalism maturely including preparing regular news and opinion papers, as well as layouts in accordance with the decisions of the editing board in carrying out its editing management. Pareno (2005, p. 145) defines editing management is the application of management functions undertaken by the editing boards through the actions of planning, organizing, mobilizing and supervising in the management of news materials which includes the process of coverage, writing, until the editing process.

Meanwhile, the task of editing according to Soehoet (2003) as follows: First, searching and gathering news. Second, processing the news and arranging its placement in the newspaper. Third, organizing administrative affairs, documentation and libraries to ease the first and second tasks. In other sources, Fadil (2014) states that the structure of newspaper editing are: general manager, supervisory counselor, legal counsel / legal counsel, editor in chief, editor of the executor, editing secretary, editing staff/ editor, reporter, graphic design, photographer, editor, correspondents, distributors, contributors, research, libraries, and documentation, and precast.

In a simpler structure, Juroto (2000) explains that media editing consists of chief editor, editing secretary, managing editor, editor, journalist (reporter), and correspondent (stinger). The six positions of the editing in its application on a publication parts and amounts may increase depending on the needs and capabilities of the press. As a campus press which structure is different from that of editors in general, the authors integrate the structure of the two experts as indicators in data analysis.

Study on the structure and function of the editorship has received great attention from several academics and scholars. Habibi (2010), for example, examined the management system applied by the Republika editorial which is open, especially regarding the similarity of information between employees and the board of editors. Further research was conducted by Driani (2013) who examines the implementation of editorial management in Janna magazine. Meanwhile, articles concerning press relations with the state were written by Rasid (2011). In the article, he stated, "The press of Indonesia is a Pancasila press in terms of a press oriented attitude and behavior based on the values of Pancasila and the 1945 Constitution." More specifically, a study of the student press is conducted by Angriawan (2012) which examines the orientation and communication strategies of the Pabelan student press. In addition, the findings show that Pabelan student press orientation is divided into two: internal orientation and external orientation. While the communication strategy used is conducted through various kinds of meetings such as discussion, pattern of implementation of control function, giving of institutional and journalism material.

Recent research on the student press was conducted by Satriani (2017) which discussed the implementation of Press Law on journalists at Washilah student press institute at UIN Alauddin Makassar 2016. The results of these studies resulted in several major points such as the legalization of the campus press, legal protection of journalists, and the design of conflict resolution.

Based on the studies and articles mentioned earlier, it can be seen that research on the structure and tasks of the editing in Soleh Solihun "s "Mau Jadi Apa?" movies is quite different. Despite examining the structure and tasks of the editing of a press, the object of this research is a movie. Research on the structure and tasks of the editors is extracted from the scenes and dialogue played by the characters in the film. This is the form of novelty that this research intends to offer.

\section{METHOD}

The research type was qualitative with descriptive method and content analysis technique. Description of the data was conducted in depth from a natural object, collection techniques with triangulation; data analysis is inductive or qualitative which emphasizing to the aspect of meaning rather than generalization (Sugiono, 2013). The data in this study were statements (can be words, phrases, clauses, and sentences) uttered from the characters and all actions related to the study of journalism. Meanwhile, the source of the data in this study was a transcription of the movie "Mau Jadi Apa?" from Soleh Solihun. The instruments of this research are the researchers as the main instrument. Researchers were assisted by members and students to upload, transcribe, understand, think, identify, and record and analyze the study of journalism in the movie "Mau Jadi Apa?" The research tools were data recording and data analysis sheet. The stages of this research were: (1) understanding structural theory and editing tasks to create research instruments; (2) downloading the movie "Mau Jadi Apa?" ; (3) watching and listening to the movie carefully; (4) reducing the data by sorting the data according to the research focus and then analyzing it assisted through the data analysis table; (5) present the data by discussing the research findings; (6) making the conclusion of the research. The validity of research data was checked through triangulation technique. 


\section{FINDING AND DISCUSSION}

Findings of structural data and editing tasks in the movie "Mau Jadi Apa?" As follows.

Table 1. Structural data and editing tasks in the tabloid Karung Goni

\begin{tabular}{|c|c|c|c|c|}
\hline No. & $\begin{array}{l}\text { Editorial } \\
\text { Department }\end{array}$ & Editing tasks & Characters & Pelaksanaan/ Tasks \\
\hline 1. & Editor in chief & $\begin{array}{l}\text { Responsible for supervising the } \\
\text { daily tasks of publishing media }\end{array}$ & Soleh & $\begin{array}{l}\text { a.leading meetings and } \\
\text { discussions. } \\
\text { b. managing } \\
\text { department. } \\
\text { c. Drafting the issue } \\
\text { outline. } \\
\text { d. Overseeing the activities } \\
\text { of junior and senior Editors. }\end{array}$ \\
\hline 2. & $\begin{array}{l}\text { Editorial } \\
\text { assistant. }\end{array}$ & $\begin{array}{l}\text { Assisting editor in chief in } \\
\text { managing administrative affairs }\end{array}$ & $\begin{array}{l}\text { Soleh } \\
\text { Fey }\end{array}$ & $\begin{array}{l}\text { Recording and archiving the } \\
\text { writings of editors and } \\
\text { journalists. }\end{array}$ \\
\hline 3. & $\begin{array}{l}\text { Managing } \\
\text { editor }\end{array}$ & $\begin{array}{l}\text { Responsible for the whole } \\
\text { implementation of news } \\
\text { gathering and deciding on } \\
\text { budget and news page space }\end{array}$ & Soleh & $\begin{array}{l}\text { Gathering selected news and } \\
\text { editing from other editors } \\
\text { then creating spaces in the } \\
\text { tabloid that will be } \\
\text { published. }\end{array}$ \\
\hline 4. & Editor & $\begin{array}{l}\text { Responsible for the contents of a } \\
\text { newspaper or magazine page. In } \\
\text { this case, the editor also covers } \\
\text { the areas of law, economics, } \\
\text { education, sports, and others } \\
\text { including language editor, } \\
\text { design and picture. }\end{array}$ & & $\begin{array}{l}\text { This editing tasks are divided } \\
\text { into several sections }\end{array}$ \\
\hline
\end{tabular}

\begin{tabular}{|c|c|c|c|c|}
\hline & a. Music editor & $\begin{array}{l}\text { Covering and writing news or } \\
\text { opinions about music. }\end{array}$ & $\begin{array}{l}\text { Soleh } \\
\text { Lukman }\end{array}$ & $\begin{array}{l}\text { Make writings in the form of } \\
\text { opinions, news, and coverage } \\
\text { contained in the Karung } \\
\text { Musik column }\end{array}$ \\
\hline & $\begin{array}{l}\text { b. Advice } \\
\text { columnist }\end{array}$ & $\begin{array}{l}\text { Covering and writing news or } \\
\text { opinions romance affair. }\end{array}$ & Fey & $\begin{array}{l}\text { Collecting the questions from } \\
\text { the reader and then giving } \\
\text { feedbacks in Karung Sok } \\
\text { Tahu column }\end{array}$ \\
\hline & c. Comic editor & $\begin{array}{lr}\text { Responsible for } & \text { illustrating } \\
\text { which supports } & \text { printed } \\
\text { journalistic writing. } & \end{array}$ & $\begin{array}{l}\text { Lukman } \\
\text { Rusli }\end{array}$ & $\begin{array}{l}\text { Creating a comic in each } \\
\text { edition along with its } \\
\text { narrative in the Karung } \\
\text { Komik column }\end{array}$ \\
\hline & $\begin{array}{l}\text { d. Citizen } \\
\text { editor }\end{array}$ & $\begin{array}{l}\text { Conducting coverage and } \\
\text { writing news or opinions about } \\
\text { student affairs. }\end{array}$ & Marcel & $\begin{array}{l}\text { Creating columns about } \\
\text { student affairs and activities } \\
\text { in Karung Analisa column. }\end{array}$ \\
\hline 6. & Reporter & $\begin{array}{l}\text { Seeking, collecting and } \\
\text { processing information into } \\
\text { news to be broadcast through } \\
\text { mass media }\end{array}$ & $\begin{array}{l}\text { All } \\
\text { members } \\
\text { except } \\
\text { Syarif }\end{array}$ & $\begin{array}{l}\text { Collecting facts and writing } \\
\text { it in news and opinion } \\
\text { column }\end{array}$ \\
\hline 7. & $\begin{array}{l}\text { Advertising } \\
\text { executive }\end{array}$ & $\begin{array}{l}\text { Served in financial management } \\
\text { and publication as well as } \\
\text { tabloid marketing. }\end{array}$ & $\begin{array}{l}\text { All editorial } \\
\text { members }\end{array}$ & $\begin{array}{l}\text { a. Publishing the tabloid } \\
\text { b. Marketing the tabloid } \\
\text { c. Managing income and } \\
\text { expenditure }\end{array}$ \\
\hline 8. & Picture editor & $\begin{array}{l}\text { Searching and displaying } \\
\text { photos related to the available } \\
\text { section }\end{array}$ & Bro & $\begin{array}{l}\text { a. Selecting models and } \\
\text { photo objects } \\
\text { b. Editing photos }\end{array}$ \\
\hline
\end{tabular}

Tabloid Karung Goni is leisure-oriented. Therefore, the columns or their constituent rubrics are very related and favoured by the common student. However, at the end of the film, coverage rubrics become more dominant, especially on coverage of „Changcuters ${ }^{\text {ee }}$ music and coverage about the behavior of unscrupulous lecturers who violate the code of ethics.

In editing tasks, the most central figure is Soleh. Soleh as the main character in this film holds various editing duties such as: general leaders, managing editors, journalists, even also participate in marketing. Soleh is also the 
originator of the idea and founder of the tabloid Karung Goni, including the creation of its name and the acronym. Not only that, Soleh himself divides the task of editings for his teammate according to their talents and interests. All responsibility and problems in Karung Goni tabloids are all given to Soleh"s figure.

Besides the tasks mentioned above, Soleh actually also served as the managing editor. The task of the managing editor here is to manage the regularity of all other editing works. Soleh is able to determine the portion of news placement (column) as well as the position of any posts from journalists or any other editors. Once in a while, Soleh also leads some meeting to determine which writings should be published in each edition.

Fey is the only woman in the editing staff of the Karung Goni tabloid. Fey's job as an editor of a heartbreaking column entitled Karung Sok Tahu. Fey also acts as secretary, treasurer, and marketing. Fey assisted Soleh in filing all the writings and administrative files of the tabloids including managing finances, from income to expenditure. As the editor of the heartbreaking column, Fey receives the reader's moans and gives feedback on the basis of her knowledge.

At the beginning of its publication, Karung Goni tabloids are not favored by readers because they are not popular. To publicize widely, Fey and Sharif undertook an effective marketing strategy: "Public Theater Techniques." This technique is done by performing a mini-theater show in the middle of college students regarding the contents of the tabloid. This technique is quite effective because it managed to increase sales of Karung Goni tabloid very drastically.

Meanwhile, other names like Marcel, Eko, and Lukman worked as editor of Karung Analisa, editor of Karung Music, and editor of Karung Komik. All three staffs are responsible for their rubric. Marcel publishes various activities and student affairs close to him. In fact, not infrequently, it comes from his own experience. In the music column, Eko operates his duties by utilizing his extensive knowledge in the music business. Eko's music column covers various types of music, singers and musicians. Due to his drawing skills, Lukman was assigned to produce comics. Lukman makes comic-series which tells about Ona and Oni. This story based on true story of the student's romance in FIKOM UNPAD at that time. In limited circumstances, the three of them also helped to market and to publish the tabloids.

The last member of Karung Goni Tabloid is Syarif. Although he does not play an important role in editing tasks, Syarif's position cannot be underestimated. His effort with Fey in composing mini theater boosts the sales of tabloid. Sharif was not reluctant to help other members within the limits that he was able to.

There are two supporting figures in this tabloid namely Rusli and Bro. Both are not the main team in the editing staff of the tabloid Karung Goni, but their role is still significant. Rusli was assigned to make this tabloid design from the beginning of the publication. Karung Goni tabloid becomes more interested in the eye of the reader through Bro "s photographs by utilizing beautiful women as his model.

All members of the Karung Gonies work in accordance with their interests and duties. They work well together. The categorization of each character's work and division can be clearly understood by the audience. Therefore, as an instructional, the movie "Mau Jadi Apa?" can be used as an alternative which can assist lecturers and students in informing and understanding editing duties.

\section{CONCLUSION AND RECOMMENDATION}

Based on the analysis, it can be concluded that Soleh Solihun"s "Mau Jadi Apa?" including in the student press which contains mass media editing, especially tabloid. The editing tasks contained in the film include: editor-in-chief, editorial assistant, managing editor, music editor, analytical editor, copy editor, comic editor, journalist and reporter, finance and marketing department, and photo editor. In general, the person in the Soleh"s group performs editing duties on a double basis, except for Syarif.

Thus, the authors recommend Soleh Solihun"s "Mau Jadi Apa?" movies can be used as an alternative instructional media, especially the journalistic elective courses. This is possible because some aspects of journalism including aspects of editing contained thoroughly in the movie.

\section{References}

Angriawan, S. (2012). "Orientasi dan strategi komunikasi lembaga pers mahasiswa Pabelan dalam menyuarakan pergerakan mahasiswa (Studi fenomenologi pada lembaga pers mahasiswa Pabelan periode kepengurusan 2012)". Skripsi. Surakarta: Program Studi Ilmu Komunikasi Fakultas Komunikasi dan Informatika Universitas Muhammadiyah Surakarta.

Arsyad, A. (2007). Media pembelajaran. Jakarta: Raja Grafindo Persada.

Fadil, F. 2014. "struktur dan jobdes organisasi majalah". [blog]. Diunduh dari http://fadhilah-ms3.blogspot.co.id/2014/01/struktur-dan-jobdes-organisasi-majalah.html. Diakses 20 Februari 2018.

Driani, D. E. (2013). “Analisis deskriptif fungsi manajemen redaksi majalah Janna” Skripsi. Jakarta: Jurusan Komunikasi dan Penyiaran Islam, Fakultas Ilmu Dakwah dan Ilmu Komunikasi, Universitas Islam Negri Syarif Hidayatullah. 
Habibi, R. N. H. (2018). "Manajemen redaksi harian Republika dalam menghadapi persaingan industri media cetak". Jurnal [online] Repository. Diunduh dari repository.uinjkt.ac.id/dspace/.../RENI\%20NURAINI\% 20PUTRI\%20HABIBI-FDK. Diakses 20 Februari 2018.

JAWA POS ONLINE. (207) "SEPEKAN TAYANG, MAU JADI APA? RAIH 80 RIBU PENONTON”. DIUNDUH DARI HTTPS://WWW.JAWAPOS.COM/READ/2017/12/06/172949/

SEPEKAN-TAYANG-MAU-JADI-APA-RAIH-80-RIBU-PENONTON. DIAKSES 10 JANUARI 2018.

Joseph, D. 2011. "Perbedaan Film dan Teater". Jurnal [onlie] Pusat Apresiasi Film. Diunduh dari e-journal.uajy.ac.id/821/3/2TA11217.pdf.

Juniarti, Gita. (2012). "Jurnalisme islam dalam pers kampus". [blog] Diunduh dari http://gitajuniarti.blogspot.com/2012/11/ jurnalisme-islam-dalam-pers-kampus.html. Diakses 10 Januari 2018.

Juroto, T. (2000). Manajamen penerbitan pers. Bandung: Remaja Rosda.

Pareno, S. (2008). Manajen berita antara idealisme dan realita. Surabaya: Papyrus.

Pramudya, W. E. (2017). "Sinopsis Mau Jadi Apa? yang Tayang Mulai Besok" Pikiran Rakyat. Diunduh dari http://www.pikiran-rakyat.com/hidup-gaya/2017/11/29/ sinopsis-mau-jadi-apa-yang-tayang-mulai-besok-414787. Diakses 29 Desember 2017.

Rasid, A. (2011). "Pola interaksi pers, pemerintah dan masyarakat dalam membentuk sistem pers pancasila:Suatu analisis retrospektif”. Jurnal [online] Sosiohumaniora, 13 (2), Juli 2011 : 189 - 210.

Satriani. (2017). "Analisis yuridis pasal 18 ayat (1) undang-undang nomor 40 tahun 1999 tentang pers (studi kasus jurnalis lembaga pers mahasiswa washila uin alauddin makassar tahun 2016)". Skripsi. Makasar: Fakultas Hukum Universitas Hasanuddin.

Soehoet, A.M. H. 2003. Manajamen media massa. Jakarta: Yayasan Kampus Tercinta IISP.

Sugiyono. 2013. Metode penelitian kualitatif dan kualitatif $r \& d$. Bandung: Alfabeta. 